\title{
BEYOND THE DOGMA OF THE FIXED BOOK PRICE AGREEMENT
}

\author{
FREDERICK VAN DER PLOEG
}

\author{
CESIFO WORKING PAPER No. 949
}

CATEGORY 9: INDUSTRIAL ORGANISATION

MAY 2003

\footnotetext{
An electronic version of the paper may be downloaded

- from the SSRN website: www.SSRN.com

- from the CESifo website: www.CESifo.de
} 


\title{
BEYOND THE DOGMA OF THE FIXED BOOK PRICE AGREEMENT
}

\begin{abstract}
After describing the essential features of the book market, a welfare analysis of the fixed book price agreement is given. Allowance is made for the opportunity cost of reading. Theoretically, the agreement pushes up book prices and depresses book sales. However, more titles will be published, particularly of books with low price elasticity and that take a long time to read. Potential advantages of better service, distribution and retail networks seem less relevant. The book market is one of imperfect competition, but even so the cross-subsidy argument is unlikely to be valid. A qualitative analysis of the Dutch situation is given. Tentative conclusions are that one should be more concerned about the number of wellstocked bookshops than the diversity of published titles and that debutantes do not face big barriers to entry. One should be even more concerned about the falling proportions of people reading books. Governments fail to set (quantitative) objectives for the fixed book price agreement, which makes it difficult to evaluate its success and contributes to it being treated as a dogma in the book world and the political arena.
\end{abstract}

JEL Code: Z11, D4, D6, L1, L4.

Keywords: book market, fixed price agreement, opportunity cost of reading, diversity, accessibility, competition policy.

\author{
Frederick van der Ploeg \\ Robert Schuman Centre \\ European University Institute \\ Badia Fiesolana - Via dei Roccettini 9 \\ I-50016 San Domenico di Fiesole (FI) \\ Italy \\ Rick.vanderPloeg@iue.it
}




\section{Introduction}

Most authors and members of the publishing and booksellers trade argue that books are different from other economic commodities. They are or should be highly valued cultural goods and cannot be left to the whims of the market. Governments should shield books from the fierce and rough pressures of competition. Otherwise, only blockbuster novels will be sold and more esoteric books, perhaps highly valuable from a literary point of view, will not be published. The government should thus grant permission for a fixed book price agreement (FBP), so that a dense network of well-stocked bookshops can survive and a large variety of books can be published. Also, monopoly profits and cross subsidies from bestsellers to less popular books allow bookshops to store a greater variety of books and allow publishers to take more risks. Critics, in contrast, hear the sirens of those addicted to the delights of a protected market. In addition, people involved in the book trade often argue for subsidies for struggling authors and for translating novels. The current practice of a FBP in combination with a variety of subsidies handed out by literary funds can only partly be explained with economic arguments. Indeed, the FBP is vigorously defended in countries such as the Netherlands and Germany and more broadly in the European Union primarily on cultural grounds. The question is whether economics can shed light on this important policy issue.

One can roughly divide those interested in books and, more generally, the arts into culture pessimists and culture optimists. The pessimists are very critical of 'the market' and suggest it leads to a money-oriented, material and one-sided way in which people live together. The culture pessimists detest a world in which everything (primarily pulp in their view) is for sale and people are merely treated as buyers and sellers of goods and services. Since the market is only interested in market power, not in culture, education or background, pessimists fear an uncivilised society. The market reduces expressions of culture to tradeable commodities. If expressions of culture, politics or religion do get mass attention, pessimists fear that they will be 'dumbed down' and may even become part of the entertainment industry. Culture pessimists have a bleak view and see the market as a pest for culture. They fear the effects of the unbridled forces of the market on the diversity of books being published and sold. Consequently, culture pessimists feel that the market must be tamed to avoid loosing high-quality bookshops and being left with only the bestsellers and the pulp. Most culture pessimists are thus in favour of a FBP.

Economists are more likely to count the blessings of the market and to belong to the camp of culture optimists. Complicated systems of centralised planning failed in the past, 
because central planners did not have and were unable to collect the gigantic amounts of information necessary to match the supply of thousands of firms to the demands of millions of households - e.g., Hayek (1988). Committees of arts experts will experience similar problems as the central planners of the former Sovjet Union. Indeed, some wonder whether the arts experts of, say, literary funds are indeed fully aware of what the public wants to read. The market mechanism often works better and leads to more social welfare. Cowen (1998, Chapter 2) argues convincingly that the culture pessimists are wrong, at least as far as the book market is concerned. The market produces an enormous variety and quality of books, not just homogenous pulp. It is extraordinary how many niches for special tastes, both high culture and low culture, the book market caters for. Globalisation and Internet allow economies of scale and reinforce the capacity of the global book market to produce diversity and variety.

Culture optimists rarely see a need for a FBP. They believe in the 'invisible hand': under strict conditions (consumer sovereignty, no information asymmetries, a full set of contingent markets, no frictions, no externalities, no public goods, no returns to scale, etc.) individual actions produce Pareto-optimal outcomes. However, there may be reasons why the book market does not function efficiently. For example, there may be public good aspects or positive externalities to do with learning to read or to do arithmetic. Although most people are vehemently against a state censorship of the written word, many are also worried about negative externalities associated with books or magazines that promote violence against or sex with children. Clearly, the FBP is not the most appropriate instrument to fix these market failures. Even if the book market is efficient, there are serious equity issues if large parts of the population become unfamiliar with the written word. A FBP may even be bad for the democracy of culture, since the monopoly prices and the cross subsidies for more esoteric books may be paid for by ordinary people reading ordinary books.

Tietzel (1995) and Rürup and Klopfleish (1997) provide a thorough analysis of the FBP with applications to Germany, Fishwick and Fitzsimons (1998) deals with the UK case, and CPB and SCP (2002) discuss the FBP in the Netherlands. This paper tries to shed more light on the economics of the FBP and assesses whether the views of culture pessimists or those of culture optimists are more relevant for the book market. Section 2 describes some general characteristics of the book market and clears up a misunderstanding often found in cultural circles about the value of culture and books in particular. Section 3 assesses the welfare costs of the Dutch FBP. To make the analysis more realistic, the cost of reading a book includes not only the price of a book but also the opportunity cost of the time that is necessary to read a book. Section 4 
discusses whether the effects of non-price competition on service, quality, availability or the number of book stores provides a case for the FBP. Section 5 argues that books are imperfect substitutes and that a framework of monopolistic competition is more appropriate than perfect competition. Section 6 discusses institutional aspects of the Dutch FBP. Section 7 concludes.

\section{Characteristics of the book market}

The book market is characterized by six distinguishing features. First, in contrast to sculptures or high-quality paintings, it is very easy to reproduce books without any real loss in quality (except perhaps for the bibliophile rare book collector). Consequently, it is easier for authors of literature to capture mass audiences than for visual artists and performing artists. The marginal cost of publishing an extra book is very low indeed. Books sell for far less than paintings and sculptures. Books offer also extraordinary value compared to the often highly subsidized performing arts. Books are in terms of reproducibility closer to videos, cd's and cd-rom's. This is why topselling authors command, especially on a global market, super incomes - see Rosen (1981). Authors catering for a niche market usually do not make a living out of royalties alone and often support their income with alternative sources of income such as lectures, subsidies or a regular (parttime) job. Books are thus reproducable cultural goods and may be called autographic art. In contrast, the expressive arts are by nature less reproducible, more unique cultural goods and are referred to as allographic art. By publishing different versions (hardback, paperback, bibliophile version, etc.), getting lending fees from libraries and author copyrights, publishers and authors can recoup part of the substantial fixed costs incurred in the production and distribution of books.

Second, cultural goods such as books benefit enormously from technological advances. Before the invention of the printing press with the publication of the first book in Western history (a Psalter) by Gutenberg in 1457, books were created one by one by hand and were more like individual allographic works of art. Once it was easy and cheap to reproduce books, writers such as Balzac, Hugo, Dickens and Tolstoy could capture mass audiences and enjoy the fruits of it. An excellent and lively overview of the (commercial) success of authors, printers, publishers and booksellers over the centuries is provided by Cowen (1998, Chapter 2). Technological advances, the Internet and lower costs of transport and communication induced a real democratization of culture while at the same time many niche books are published that do not cater for the average taste (the greatest common denominator). More people have the possibility of access to the written word, in book or electronic form, than ever before. This upsets 
conventional arrangements for publishing and distributing books. For people wanting specialized or less popular titles or living in less populated areas with no easy access to well-stocked bookshops, these developments may be a blessing. Although many people still prefer to smell, hold and read a book, the Internet provides a very useful and popular hands-on and interactive approach to reading and searching for interesting things to read. Also, in the future printing \& publishing on demand and well-designed E-books will become more popular. The Internet has already become an invaluable source of reference for quotes, dictionaries, medical information, travel information etc. and has thus replaced many hefty paper reference volumes. A distinguishing feature of E-books is that they are weightless rather than physical cultural goods, which can be reproduced at any time and at any place in the world and can be obtained much more cheaply. Weightless E-books are also more likely to be non-excludable, non-rival goods and thus to have the character of a public good. Hence, E-books are more likely to warrant government subsidy than traditional physical books which have more of a rival and (apart from lending to friends) excludable nature. Although still a fairly small percentage of books is sold through the Internet, book suppliers on the Internet already provide an invaluable service to those searching for books not found in the local bookshop. Also, the advice offered by book suppliers on the Internet on related titles that may be of interest is appreciated. By offering free previews of book titles on the Internet, publishers wet the appetite of potential readers and sell more books.

Third, it takes time to read and enjoy a book that is worthwhile. People have a hard time trying to fit in work, travel, shopping, cooking, eating, washing, cleaning, child care, holidays, sport, other forms of leisure, seeing friends, sex and sleep, let alone have time for reading a book. The opportunity cost of spending several hours or even days reading a particular book must be added to the cost of buying or borrowing that book. In fact, this extra opportunity cost may be several factors greater than the cost of the book itself, especially if it is a book one has to take trouble and time for to understand and appreciate. This extra cost lowers the effective price elasticity of demand and thus raises the monopoly power of publishers and booksellers. In this sense, books are not different from visiting the time-consuming performing arts (think of hours watching, listening to and experiencing Wagner's Ring) or going to the cinema. Many people take less time to visit expositions of painting or sculptures. An important corollary is that higherincome people face a higher cost of reading a book than lower-income people, so that a higher income induces a less than pro-rata increase in the demand for books. This partially offsets the phenomenon that high-culture books may be luxury goods in the sense that people demand more 
books as their income rises. Also, books that cannot be read quickly (often of high cultural value) have a higher cost as well and a lower elasticity of demand with respect to the book price. They are thus more vulnerable to monopoly pricing.

Fourth, reading a book can be a memorable experience. Reading Hamlet, A Hitchhiker's Guide to the Galaxy or Harry Potter at a young age may lead to lifelong memories of a worthwile experience. Reading books may be viewed more as a private (or even social) investment in cultural capital rather than merely as consumption. This is what sets culture and literature books apart from instant entertainment. Also, reading books is an acquired taste. It is an experience good. The more one reads worthwile books, the more one gets out of it, is able to appreciate the context and develops an appetite for it. The preference for reading books is not given, but shaped by education and experience. Private spending on shared cultural goods such as books thus contributes to the social stock of cultural capital. Hence, books also have intergenerational, bequest or option value.

Fifth, some books offer a small elite the chance to distinguish themselves from the rest of the population, cf. Bourdieau (1979). Indeed, there are books that offer snob appeal to some. Such an elite is well able to press its arguments in favour of a FBP. If politicians want to be seen to be part of this cultural elite, they may fall for these arguments even though this may not be in the interests of their electorate. In contrast, others stress the positive external effects of books. Reading a book may lead to a shared cultural experience and readers will tell others about the wonders they have read. It may thus be that the market supplies insufficient book titles and that there is a need for the government to step in by financing, for example, literary funds. Many argue that books are merit goods and that society must make sure that they are published, even though there is apparently insufficient demand for them and may only be enjoyed by a small elite. Many argue that it would be good from the cultural point of view if the majority develops an appetite for reading books as well. This merit-good argument presumes a paternalistic attitude of the government and thus violates consumer sovereignty. Also, unsubsidized books typically draw a bigger public than subsidized books. It may be more effective to stimulate reading of books by funding public libraries and encouraging reading at schools.

Sixth, there is increasing evidence that society is becoming more one of images rather than of the written word. Books are facing stiffer competition from television, film and Internet.

Before we analyze the economics of the FBP, we clear up a misunderstanding that is prevalent in many discussions about cultural policy. Throsby (2001) points out that there are many cultural 
values, such as aesthetic value, decorative value, spiritual value, social identity value, historical value, symbolic value, authenticity value, etc. Many of these cultural values apply to books as well, but we should be careful to distinguish them from the economic value of books such as use value, exchange value, status value, option value, etc. Bibliophiles are aware of the store value of some books, while society at large may be concerned with the option value and bequest value of the written word for future generations. Of course, economists can not pretend that they know the value of a published book. Still, many eloquent defenders of culture and of the professional book community accuse economists of equating the value of books to the price of books. This explains a lot about the tower of Babylon, which seems to exist where economics and culture meet. Economists treat value as a subjective concept, namely the amount an individual person is willing to pay for a particular book. Typically, that is much more than what they actually paid for that book. Even the most ardent marginalists do not equate price with value. In fact, the amount people are willing to pay more than what they actually paid, is the consumer surplus and

contributes to social welfare. Similarly, book suppliers may have been prepared to have supplied at a lower price than the price they actually fetched on the market. The difference is the producer surplus, which contributes to social welfare too.

\section{Welfare analysis of the fixed book price agreement}

Here we compare the competitive equilibrium (CE) with the monopoly outcome for the book market. Effectively, we are assessing the effects of a FBP which lasts forever. In practice, the Dutch FBP allows prices of a particular book to be fixed for a period of two years. Afterwards, prices must be free and books can be sold with a discount. It thus seems reasonable to assume monopolistic pricing during the first two years and competitive pricing afterwards. This situation allows for intertemporal effects and is a bit more cumbersome to work out - see the Appendix.

To allow for the opportunity cost of having to curl up and take time to read a book, let $\phi$ be the hours spent reading a book. It follows that $\phi W$ is the opportunity cost of the time needed to read a book, where $W$ stands for the (constant exogenous) wage rate. It corresponds to the foregone opportunity of making money by working and should be added to the price of a book. We also allow for a sales tax $T$. The full cost $Q$ thus includes the price of the book, the sales tax and the opportunity cost of the time needed to read a book, that is $Q \equiv(1+T) P+\phi W$. Households have one unit of time available, which they use to work $(1-\phi B)$ or read books $(\phi B)$, where $B$ indicates the number of books bought and read. People who do not read enjoy maximum labour income $W$. Although there is no utility of leisure, there is utility of buying and taking time 
to read books so that labour supply is endogenous. We assume that utility is quasi-linear in consumption of other goods $C$, say $U(B)+C$ with $U^{\prime}>0, U^{\prime \prime}<0$, and is maximized subject to the household budget constraint, $Q B+C=M+W$ where $M$ stands for non-labour money income.

The demand for individual books follows from setting the marginal rate of substitution between books and other consumption goods equal to ratio of the full cost of books to the price of other consumption goods. With quasi-linear preferences the marginal utility of private consumption equals one, so that the demand for books follows from $U^{\prime}(B)=Q$. Taking logarithms we obtain the following demand for a particular book title:

$$
b \cong-\varepsilon[(1-\beta)(p+t)+\beta w] \text { with } \varepsilon \equiv-Q / B U^{\prime \prime}>1 /(1-\beta) \text { and } \quad 0<\beta \equiv \phi W / Q<1
$$

where lower-case romans denote logarithmic deviations or relative differences (e.g., $b \equiv d B / B$ except $\mathrm{t} \equiv \mathrm{dT} /(1+\mathrm{T})), \varepsilon$ denotes the elasticity of the demand for books with respect to the full cost of reading a book, and $\beta$ stands for the share of the opportunity cost of the time needed to read a book in the full cost. The elasticity of the demand for books with respect to the price of books, $\varepsilon(1-\beta)$, is less than $\varepsilon$, since the price of a book is only part of the full cost of reading a book. To have positive marginal revenue, we assume $\varepsilon(1-\beta)>1$. Other consumption follows residually from the household budget. It rises with total full-employment (no-reading) income $M+W$ and the cost of reading a book $Q$ (as $Q B$ falls).

Publishers/booksellers maximize profits, $P B-K(B)-F$ with $K^{\prime}>0$ and $K^{\prime \prime}>0$, where $K(B)$ denotes variable costs and $F$ fixed costs. Alternatively, we could assume conflict in objectives of publishers/bookshops and authors. The former maximises profits, but authors (especially if they have other income to rely on) may (rationally) prefer to maximise sales in order to maximise the impact of their writing. Such authors prefer their books to be on sale at a lower price than publishers/bookshops. Their loss in royalties may be made up by extra income from lecture tours, teaching, etc. To keep things simple, however, we assume profit maximisation. Under perfect competition firms then set prices to marginal cost, $P=K^{\prime}(B) \equiv P^{*}$.

The FBP effectively grants the book trade an exception on the competition bill. This means that publishers/booksellers can collude in setting retail prices for books. The extent to which it is possible to exercise monopoly power depends on the degree of substitutability of the content of a particular book title. A low degree of substitutability allows for a high producers' price, which is under the Dutch FBP imposed on book retailers. Publishers/booksellers thus set prices above marginal cost, $P=K^{\prime} \varepsilon(1-\beta) /[\varepsilon(1-\beta)-1] \equiv P^{* *}>K^{\prime}$. Clearly, under the FBP prices are 
set higher if the price elasticity is low. This is the case if there are few substitutes for the content available and if the price of a book is only a small part of the full cost. Publishers/booksellers can then raise prices without being punished too much, since demand does not fall that much. Monopoly power is thus large if few substitutes for the content exist and if the wage is high and a lot of time is needed to read a book. A corollary is that booksellers find price discrimination profitable, whereby high-income earners get charged a higher price for books. Upon substitution of the pricing equation into demand, we obtain equilibrium sales of an individual book title

$$
b=-\varepsilon[(1-\beta)(t+m)+\beta w] /\left[1+\varepsilon(1-\beta) K^{\prime \prime} B / K^{\prime}\right]
$$

where $m$ is zero under perfect competition and equals the relative change in the mark-up under the FBP. In equilibrium book sales of a particular title rise if the sales tax is cut or the wage falls.

Figure 1 shows the effects of the FBP. At the competitive equilibrium, $P^{*}$ and $B^{*}$, the willingness to pay equals the area under the demand curve $\mathrm{x}+\mathrm{y}+\mathrm{z}+\mathrm{v}+\mathrm{w}+\mathrm{a}+\mathrm{b}$, which is more than consumers actually paid $\mathrm{v}+\mathrm{w}+\mathrm{a}+\mathrm{b}$. Subtracting total production costs $\mathrm{v}+\mathrm{w}+F$, we obtain profits $\mathrm{a}+\mathrm{b}-F$ plus the consumer surplus in competitive equilibrium $\mathrm{x}+\mathrm{y}+\mathrm{z}$. The welfare analysis thus allows for the fact that publisher/booksellers would have been prepared to deliver books below the equilibrium price. At the FBP, $P^{* *}$ and $B^{* *}$, the willingness to pay equals $\mathrm{x}+\mathrm{y}+\mathrm{a}+\mathrm{v}$. Again subtracting production costs $\mathrm{v}+F$, we obtain profits $\mathrm{y}+\mathrm{a}-F$ plus the consumer surplus $\mathrm{x}$ under the FBP. The loss in welfare resulting from the fixed book price is thus equal to the area of the familiar 'triangles' $\mathrm{z}$ (the consumer loss if profits $\mathrm{y}$ are distributed to households) and $\mathrm{b}$ (the producer loss). The FBP effectively prevents retail outlets to compete on price, so prices of individual book titles are higher and revenues of each title are lower. In addition, retailers are unable to differentiate prices according to location, quality of service offered to customers, to offer discounts on unpopular books, and to introduce loss leaders.

Under the FBP firms only publish/sell a particular book title if sales revenues $y+a+v$ exceed costs $\mathrm{v}+F$, that is if profits are positive or $\mathrm{y}+\mathrm{a}>F$. In competitive equilibrium an individual book title is published/sold if profits are positive, that is if $\mathrm{a}+\mathrm{b}>F$. Clearly, if fixed costs $F$ are very high, less book titles will be published and sold as then it is less likely that sales revenue minus variable costs are high enough to cover fixed costs.

Since profits under monopoly pricing are evidently higher than profits in a competitive equilibrium $(\mathrm{y}+\mathrm{a}-F>\mathrm{b}+\mathrm{a}-F)$, more book titles are profitable and thus more book titles are published/sold under the FBP than in competitive equilibrium. It is possible to print and sell 
extra books at low and almost non-increasing marginal cost, so that the producer loss b is likely to be small. Also, the price elasticity of the demand for books $\varepsilon$ is likely to be small as a large part of the full cost of reading is the opportunity cost of time. Hence, the monopoly mark-up is likely to be large and monopoly profits y are large. It thus seems likely that many more book titles are published under the FBP than under perfect competition. Some monopoly profits are necessary for marginal book titles to recoup fixed costs, which is not feasible under perfect competition. However, if a particular book title is published, less copies will be sold at a higher price than in competitive equilibrium. Even though the FBP leads to more variety in book titles published, prices will be higher and sales of each book title lower.

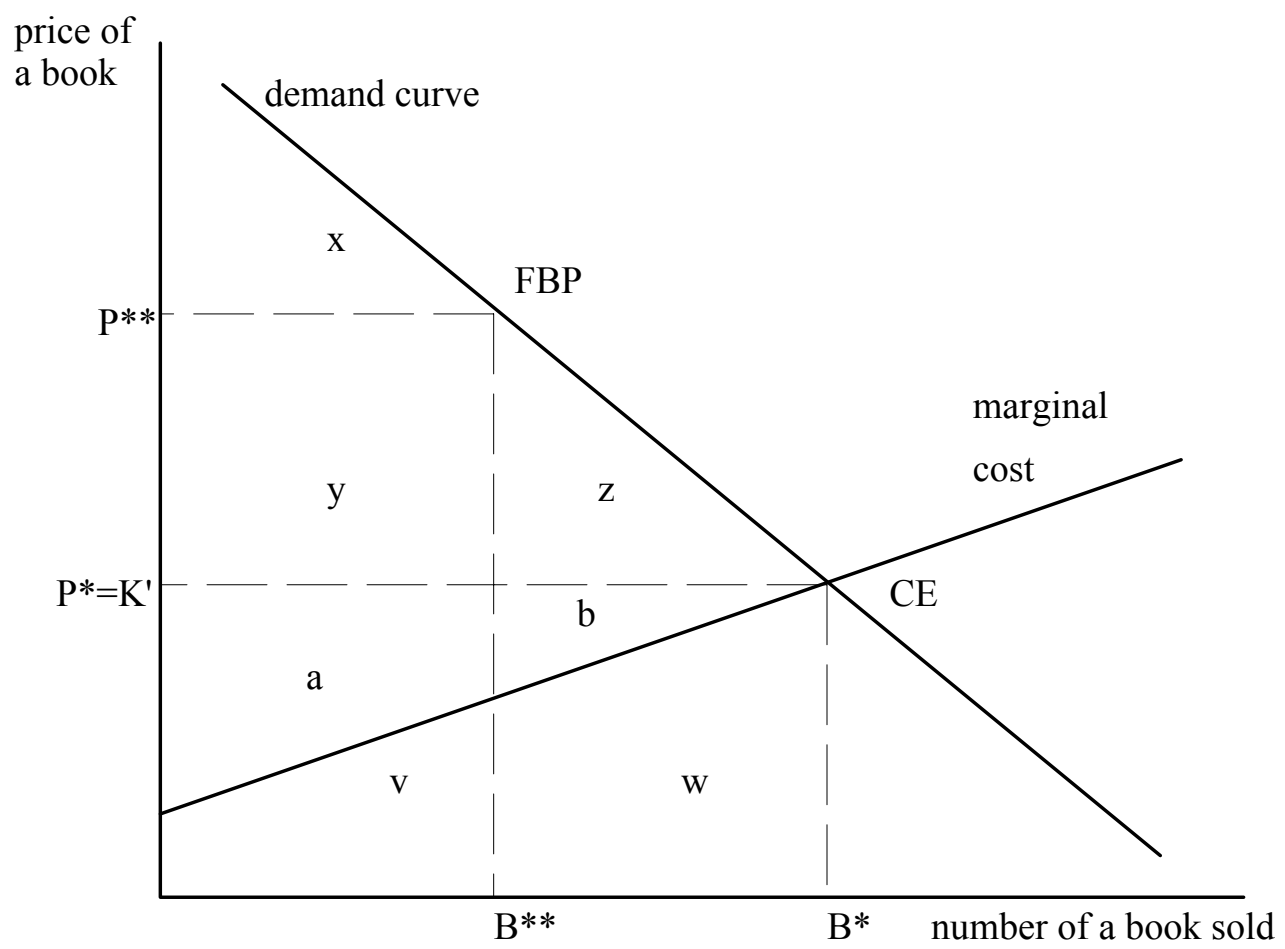

\section{Figure 1: Welfare costs of the fixed book price agreement}

The FBP also implies that publishers/bookshops are reluctant to change prices of books if aggregate demand for books changes - cf., Mankiw (1985). If publishers/booksellers have to incur ex post 'second-order' menu costs of changing book prices, it is suboptimal for an individual publisher/bookseller to cut its price following a contraction in demand even though it is socially optimal to do so. The envelope theorem implies that, at a profit-maximizing optimum, each individual publisher/bookseller only has a 'second-order' gain profits from changing prices. 
However, all publishers/booksellers have a joint 'first-order' incentive to lower prices. Hence, the book trade is under the FBP, in contrast to under the competitive outcome, likely to get stuck in a non-cooperative outcome with too high book prices and too low sales. The menu cost argument thus adds to the costs of the FBP.

There is also a political economy argument, which adds to the costs of the FBP. It says that the welfare costs of the FBP are much higher than the sum of the consumer and producer surplus 'triangles' discussed above. Tullock (1980) argues that publishers and booksellers lobby and spend time, energy and other resources to get and maintain the privileges of the FBP. It is unrealistic to assume that monopoly profits $\mathrm{y}+\mathrm{a}-F$ are handed back to consumers. Publishers and booksellers go on with lobbying and rent seeking until a large part of these profits are dissipated. Hence, as rent seeking amounts to wasted resources, one should add monopoly profits $\mathrm{y}+\mathrm{a}-F$ to the true costs of the monopoly agreement so that the total welfare loss is $\mathrm{y}+\mathrm{a}-F+\mathrm{z}+\mathrm{b}$. In fact, if these profits are dissipated to some extent, the gain in the diversity of book titles will evaporate as well. Adam Smith already stressed the costs of rent seeking in the context of the privileged positions under mercantilism, but rent seeking is also a crucial element in analyzing the book market and, more generally, in cultural economics.

Apart from the standard static welfare costs and, possibly, lobbying costs as well, a FBP also has dynamic costs. Of course, price competition between retail outlets becomes impossible but it is also more difficult to vary prices in response to local conditions. A store on Vlieland (a remote island in the Waddenzee in the north of the Netherlands) may want to charge more for the same book as a store in a Amsterdam close to the publisher, but is under a FBP constrained to charge the same price. Also, it is more difficult to vary prices for different types of customers or for different seasons. Some customers want no service and low prices, while others prefer service at a higher price. Most important is that a FBP discourages the development of innovative distribution channels, since realised cost savings cannot be passed on to customers. In countries without a FBP, one expects more use of the Internet to sell books than in countries with a FBP. Indeed, the price of books will pit independent small bookshops against the big chains, supermarkets and the Internet. This seems indeed to be the case for the UK and the US. With a FBP, unconventional distribution channels (bookclubs, supermarkets, petrol stations, the Internet, etc.) have less of a chance. Against these costs should be balanced the benefit that independent small bookshops are often able to recommend interesting books and order books that are not in stock from the publisher or distributor.

The analysis above thus suggests that the FBP leads to a bigger diversity of book titles (if 
not all profits are dissipated by rent seeking) and better incentives to develop new distribution channels, but higher prices and less sales revenues for each title and perhaps less conventional bookstores. However, the experience of the UK after liberalization suggests that, while the number of bookstores has declined and new channels of distribution have opened up, book prices have gone up by more than the retail price index. Liberalization of taxi fares has also raised taxi fares. Some taxicabs ask much higher prices to capture a share of the uninformed tourist trade while others charge lower prices and enjoy a higher business volume targeted at the undiscriminated tourist trade and the residents' market - e.g., Salop and Stiglitz (1977) and Sutton (2000). In the book market competition may fail for different reasons than in the taxicab business, since the public can with the aid of the Internet quickly inform itself about prices of book titles. A different problem may be that the book market may fail to produce an efficient outcome, because part of the public has difficulty in assessing the quality of particular books at the moment of purchase (and thus before the book is read). This problem of imperfect information leads to a 'lemon' problem in which bad-quality books may drive out good-quality books- see Akerlof (1970). Eventually, the market for high-quality books may thus collapse.

\section{Does a fixed book price agreement promote non-price competition?}

Although the FBP has welfare costs and benefits, many in the book trade argue in favor of it. They argue that, even though competition through the price of a particular book is eliminated, competition between publishers or bookshops on non-price factors may well intensify. Also, various kinds of non-price competition may take over from price competition. Obviously, this may have cultural benefits.

A larger sales margin stimulates booksellers to give a better service to customers - see, for example, Holahan (1979), Mathewson and Winter (1998), and Deneckere et al. (1996). With a bigger profit margin, it pays to spend more effort on service in order to get extra customers. If the extra service (more attractive presentation in bookshops, better information to customers, more promotion, etc.) generates more sales than the fallback in sales due to the higher monopoly prices, a FBP may be desirable. The market fails and delivers not enough service, because bookshops have an incentive to operate as free-riders by offering discounts and expecting their customers to get their information and service elsewhere. Bookshops can hardly refuse service or charge for information of people that are in the end not going to buy a book. Still, it seems a bit far-fetched that customers engage in such a strategy, as the costs of roaming around various bookshops seem too high in relation to the possible discount one might obtain. Also, much of the 
service is made available through advertisements of the publisher or book reviews in the newspapers and other media or on the Internet. Anyway, it is questionable whether the demand for books really depends on the service. It is thus unlikely that better service is a valid argument for supporting a FBP.

The book trade also argues that a bigger margin gives incentives for better-stocked bookshops. Booksellers may take over some of the inventory risks from publishers, so that more titles can be published. In the margin it is more profitable for retail outlets with relatively high costs to open up. This argument only works if there are customers who only want to purchase their books at particular high-cost bookshops. In that case, the gain in sales from these outlets offsets the drop in sales resulting from higher monopoly prices. Although a dense network of bookshops may indeed be desirable from a cultural point of view, it is unclear that this argument for a FBP can be justified on the grounds of market failure. Another popular argument in favor of the FBP is that higher margins encourage more retail outlets to put new book titles with uncertain sales prospects on their shelves. Given that there seems to be no problem for debutantes to get their first book published, this does not seem a strong argument (also see section 5). Marvel and McCafferty (1984) suggest that resale price maintenance may sustain a luxury image, but that does not seem a very relevant argument for the book market.

In sum, the above discussion does not provide clinching arguments for a FBP. Even if a case can be made on the basis of a greater variety of book titles being published under a FBP, one wonders whether there are not more efficient instruments than a FBP.

\section{Books are imperfect substitutes: Is the cross-subsidy argument really valid?}

Sections 3 and 4 assumed that books are homogenous goods. However, the novel Endurance by Ian McEwan is no perfect substitute for Harry Mulisch's epic novel Ontdekking van de Hemel (Discovery of Heaven). They are different books, because the authors have different styles, the themes of the two novels are very different, and last but not least the original languages in which the books are written are different. Still, Mulisch's books are closer substitutes for the novels of Ian McEwan than, say, a cooking book or a travel book. On the other hand, Martin Amis may be a closer substitute than Harry Mulisch for Ian McEwan. It is clear that each author can carve out a niche in the book market, so that the assumptions of perfect substitutes (homogeneous books) and thus a competitive book market are plainly unrealistic. If an Alfa Romeo Spider differs from a Golf cabriolet, a Triumph Spitfire, a MG-Midget or a Fiat Barchetta, then clearly the work of each author must be different. One must thus leave the realms of perfect competition and adopt a 
framework of Chamberlinian monopolistic competition where books are imperfect substitutes. Publishers/booksellers carve out a niche and make monopoly profits, which enables them to recoup fixed costs. It is thus profitable to publish books even though the marginal cost of printing extra books is very small. In fact, the lobby of booksellers/publishers often resorts to the argument of imperfect competition. They argue that the FBP allows for cross-subsidies from bestsellers towards less popular books and leads to a more diverse supply of book titles and bookshops. In addition, publishing and stocking a large selection of books enhances reputation, yields economies of scope and satisfies the idiosyncratic taste of individual publishers and booksellers.

The cross-subsidy argument seems at first blush a trifle irrelevant. In competitive markets with imperfect information about the success of a product, it is common to invest in many products and reap a success on only a few of them. Even though there is no fixed horseprice agreement, horse owners typically purchase lots of yearlings, many of which subsequently are sold to the riding school or the butcher if they do not win any races. Similarly, in a market without a FBP publishers invest in debutantes just like horse owners invest in yearlings. In fact, there are few barriers for debutantes on the book market and publishing is a risky business with only a third of published books being profitable. In any case, the cross-subsidy argument is unlikely to hold if bestsellers are highly price-elastic and less popular, more esoteric books are price-inelastic. Monopoly profits on bestsellers are then small, while less popular, more esoteric books command lots of monopoly profits. The FBP then has all the welfare and political economy costs of a monopoly. This situation may arise if bestsellers are easily digestible, require little time to read and thus have high price elasticities of demand, while, say, poetry readings demand a lot of time and effort and thus have low price elasticities of demand. Indeed, anything worthwhile from a cultural point of view takes time and effort to appreciate and thus has a low price elasticity of demand and commands monopoly power. The point is that the price of a good book should be supplemented with the opportunity cost of the time devoted to reading the book, which can be very high. Hence, books with great cultural value are more susceptible to monopoly power. In that case, a FBP obtains most of the monopoly profits on less popular books and the cross-subsidy argument fails.

Non-fiction books (dictionaries, cooking books, travel guides, textbooks, etc.) are likely to be close substitutes within each genre and will thus have high price elasticities. Fiction books (children books, detectives, etc.) often have close substitutes, especially for the pocketbook versions of old titles, and thus high price elasticities. We do not expect large monopoly profits on 
such titles and there is little room for cross subsidies to books with a specialist or unique character. Such books have low price elasticities and generate high monopoly profits. If this is the situation, the cross-subsidy argument is likely to be a theoretical curiosity.

The problem with a FBP is that there is no guarantee that publishers/booksellers use the monopoly profits to make sure more esoteric titles are published and stocked in the stores. It may well be that monopoly profits are directed towards unproductive managerial slack. Since it is very unclear what the objectives of a FBP are, it is almost impossible to gauge the failure or success of such an agreement.

\section{Is the Dutch fixed book price agreement harmful?}

Detailed information on the Dutch FBP may be found in CPB/SCP (2002). It distinguishes three criteria to gauge the success of a FBP: (1) a diverse supply of book titles as indicated by the number of book titles, number of genres of books, number of literary or cultural titles or number of literary or cultural genres of books; (2) wide availability of books as measured by the number of sales points, the width of the assortment per sales point or the number of sales points with a broad and a limited assortment; and (3) participation of the public as measured by the proportion of people who read in the various segments of society, the proportion of people who purchase or read books and what kind of books (general or literary, etc.) people read.

As far as (1) is concerned, in 2000 there were 26.779 (43\%) literary, cultural books published in the Netherlands. This covers everything from children's books, novels, poetry and literary essays and journals to history, philosophy and other cultural books. A very broad and diverse spectrum of books is published corresponding to a diverse supply of literary and cultural book titles. As far as (2) is concerned, there seems a dearth of bookshops in parts of the north of the Netherlands but not in the cities. On average bookshops stock a little less than 5.000 titles, merely $8 \%$ of all titles. However, the $10 \%$ and $1 \%$ of best-assorted bookshops stock almost three $(23 \%)$ and five (37\%) times as much. The bigger bookstores have a greater variety of literary, cultural titles in stock. For example, the $10 \%$ of best-assorted bookshops stock 5.589 of such titles while the average bookshop stocks 2.132 of such titles. There are 1.29 bookshops per 10.000 inhabitants in the Netherlands compared with 1.69 in France and only 0.55 in the UK and 0.44 in Flanders. This suggests that a FBP leads to a bigger density of bookshops, but this does not take account of differences in population density. The number of bookshops was already falling when the UK abolished the FBP. Subsequently, book sales through the Internet, supermarkets and other innovative channels seem to have been stimulated - see Fishwick and 
Fitzsimons (1998). On the other hand, in France the number of bookshops increased when the agreement was temporarily abolished. As far as (3) is concerned, in a survey of a week in October 2000 the Dutch people spent on average only 0.9 hours reading a book of which less than a quarter spent more than one hour reading a book. Older and higher educated people and women read more than average. There is no noticeable difference in reading between low- and high-income groups, although higher incomes tend to purchase books more often rather than borrow them from the library.

The Dutch government allowed the FBP to be exempted from the competition bill in 1990 for a period of 15 years, without giving any criteria for success or failure of this "cultural exception". Just some vague reference to the idea that the agreement might promote a diverse supply of book titles was given (see section 5). Clearly, it makessense to introduce explicit targets for (1), (2) and/or (3) above.

The Dutch FBP as stated in the "Reglement Handelsverkeer" of the KVB is not comprehensive. It is restricted in time and does not apply, for example, to import books (forbidden by the European Commission), bibles, church books, diaries, second-hand books and antiquarian books. The Dutch government will also exclude schoolbooks and scientific books from the agreement, so parents can buy books collectively and scientific publishers no longer charge university libraries excessive prices. Special prices can be set for books bought from book clubs or with special vouchers, for books that one has to sign on for before publication, and for books that appear in a series, in combination with other articles or as part of a special promotion. Discounts may be given for public libraries and for business-relations presents, but also if one buys a large number of a particular book. Since the FBP does not apply to damaged books, distributors can circumvent the agreement by deliberately tearing or folding a page a little. There are thus many sensible exceptions to the Dutch FBP and, in any case, the agreed price only holds for two years. Hence, the costs of the Dutch FBP (see section 3) are likely to be modest.

However, the Dutch FBP also stipulates that exclusive distribution rights with a trade margin are only given to certain distributors. Other distributors only get a trade margin for books up to 20 Euro. Acknowledged distributors get a margin of $15 \%$ for books above 20 Euro. This amounts to roughly one sixth of all books. The Dutch FBP also stipulates that bookshops are not allowed to sell books from not-acknowledged publishers if they cost more than 30 Euro. A total of 1.555 bookshops, 8 Internet-retailers, 522 other retail outlets, 3 book clubs, 25 wholesalers and importers, and 500 publishers have joined the Dutch FBP. As much as $70 \%$ of general books sold fall under the FBP, but more than a quarter of these are sold at a discount through book 
clubs. Only $6 \%$ come from not-acknowledged publishers, about $10 \%$ are imported and the remaining $14 \%$ are sold with discounts as returns. Since many people use libraries, only $10 \%$ of books that are read fall under the FBP.

A further restriction of competition in the Dutch book market is that wholesale deliveries out of the central depot of the "Centraal Boekhuis" receive a fixed discount of $42 \%$ (about 39\% after distribution costs) on general books and $20-28 \%$ on school and scientific books. Effectively, this restricts the price the publisher can charge bookshops to about $61 \%$ of the final sales price for general books and sets a floor in the trade margin for bookshops of $39 \%$. There is another reason why book retailers have a strong bargaining position. Publishers have to fight to get their books on the shelves of as many retail outlets as possible, since more than 12.000 new titles are published each year in the Netherlands while most bookshops can store at most 5.000 titles (including imported and old titles). Many bookshops derive bargaining strength also from their geographic location. The power of bookshops is especially great for chains and larger stores.

\section{Concluding remarks}

The standard case against the FBP is that book prices are higher and sales lower than in competitive equilibrium. This hurts the interests of book buyers and particularly hits the lower incomes. One may, nevertheless, argue on cultural grounds in favor of a FBP, since this may lead to more and better-stocked bookshops and to publication of a larger number of marginal book titles. Although of books that are published prices are higher and sales lower, more titles will be published and more bookshops will carry a diverse assortment of popular and less popular books.

However, the cross-subsidy argument in favor of a FBP is not convincing. First, the market will even without a FBP cross-subsidize debutantes and other risky projects in the hope of getting possibly a best seller. Second, even if this cultural policy works, there is no accounting for what is done with the cross subsidies and there are no democratic checks and balances. Third, there is no guarantee that profits on bestsellers are used to cross-subsidize less popular, more esoteric books. In fact, publishers and booksellers have an incentive not to do this. Fourth, if less popular, more esoteric books are less price elastic (if only because they take more time to read) than popular books, monopoly profits on less popular books will be higher and the cross-subsidy argument does not work. Fourth, even if the cross-subsidy works, one should evaluate whether the cultural gains from cross subsidies outweigh the distortionary costs of the FBP.

Other arguments in favor of a FBP that stress improved service, better distribution and retail networks, and other forms of increased non-price competition do not stand up to scrutiny 
either. The Dutch book market produces a large variety of titles and debutantes do not experience severe problems. Although bookshops have a powerful bargaining position, one should worry about the declining number of well-stocked bookshop outside the big cities.

The FBP hinders Internet suppliers and supermarkets trying to sell books. Still, many granted privileges and other monopoly positions will be undermined by technical changes. Digital cameras and recording \& editing equipment make low budget radio and television as well as narrowcasting possible, thus undermining the monopoly position of public and other broadcasters. Similarly, the Internet stimulates the advent of virtual book suppliers such as Amazon.com, printing \& publishing on demand and E-books. It makes publishing possible for almost anyone, thereby undermining the monopoly position of traditional booksellers and publishers. Virtual dictionaries, encyclopedia and other handbooks have already overtaken to a large their extent their physical counterparts. Although Internet will never be a perfect substitute for a dense network of well-stocked bookshops, more retailing will in the future probably take place through the Internet.

The UK, Sweden, Finland, Belgium and Ireland do not have a FBP, but the latter two countries are thinking of introducing a FBP. France, Italy, Spain, Portugal, Greece, Austria, Luxembourg, Denmark and most recently Germany have anchored fixed book price agreements in the law. Most of these are based on the French law (the "loi Lang"). The Netherlands exempts collusive agreements of the book trade from the competition bill, but has not anchored the FBP in the law as such. Some countries (e.g., Italy, Denmark, Spain and soon the Netherlands) exclude schoolbooks from the FBP. Hence, the FBP is with the exception of the UK, Sweden and Finland popular throughout Europe - see, e.g., EIM (2001). Most European Ministers of Culture see the FBP as a treasured dogma against the whims of the market. In future research it is desirable to study cross-country evidence and investigate the empirical effects of the FBP.

The European Commission is not in favor of the FBP, which it sees as an infringement of the common market ideal. However, the European Commission (2002) recently gave up competition proceedings against the German book price fixing system (the 'Sammelrevers'). The reason was that German publishers and booksellers gave sufficient undertakings for their FBP not to hinder appreciably trade between member states and thus not to infringe the European Union competition rules. Effectively, this guaranteed the freedom of direct cross-border selling of German books to final consumers in Germany, in particular, via the Internet. German publishers and booksellers thus will not hinder or put an embargo on direct cross-border Internet sales and advertising of cheaper German books by foreign retailers. They agree not to violate the 
'Sammelrevers', so that they will not cooperate with foreign retailers in order to circumvent the FBP. This prompted European Commissioner Mario Monti to say: "On the basis of EU competition law the Commission has no problem with national book price fixing systems which do not appreciably affect trade between member states. By clearing the German price fixing system the Commission, in a perspective of subsidiarity, also takes account of the national interest in maintaining these systems which are aimed at preserving cultural and linguistic diversity in Europe." There are thus no European obstacles to national book price fixing agreements, provided that they do not hamper cross-border trade.

The Dutch FBP may lead to higher prices and less sales of any book title that is published. It may also hinder innovation and distribution, but more titles will be published and there will be more bookshops with a diverse assortment of titles. In any case, the Dutch FBP is of limited duration and characterized by sensible exceptions. The welfare costs are, if any, probably not very large, but may be reduced a little by reducing the term and coverage of the agreement. CPB/SCP (2000) sensibly suggests reducing the term from two years to six months, not permitting extension of the duration of the fixed price, excluding scientific books, abolishing certification and exclusive trade arrangements, scrapping the fixed discount for recognised booksellers, and moving to individual rather than vertical price agreements. The alternative of subsidizing bookstores in order to maintain a dense network of well-stocked bookshops will probably be an administrative nightmare. Subsidizing publishers to publish books of literary and cultural value also seem to hinder the market mechanism and lead to adverse effects. In fact, in Sweden the government subsidises in this manner roughly a third of all fiction and a fifth of books for the youth. However, in Sweden retailers stock not all titles as the government rather surprisingly does not require subsidised books to be sold. Being the dogma that it is, the FBP unfortunately diverts attention and energy away from making the book trade more innovative and customer-oriented. It may be more worthwhile to improve reading of a wide variety of books that are published in the Dutch market by investing in public libraries and education, subsidizing authors to write books of high cultural value, translating the best books into other languages and promoting them abroad.

\section{Appendix}

This appendix analyses a FBP with duration two years. We denote purchases of books during the first two years by $B^{F}$, purchases afterwards by $B^{C}$ and the corresponding producer prices by $P^{F}$ and $P^{C}$, respectively. Consumers choose $B^{F}$ and $B^{C}$ to maximise utility, viz. 


$$
\operatorname{Max} U\left(B^{F}\right)+(1+\rho)^{-1} U\left(B^{C}\right), \quad U^{\prime}>0, U^{\prime \prime}<0
$$

subject to the budget constraint

$$
\left[(1+T) P^{F}+\phi W\right] B^{F}+(1+R)^{-1}\left[(1+T) P^{C}+\phi W\right] B^{C}=M+W
$$

where $\rho \geq 0$ stands for the rate of time preference and $R \geq 0$ is the market rate of interest. Clearly, the marginal rate of substitution between books now and books two years from now must equal the relative consumer price (including the sales tax and the opportunity cost of reading):

$$
U^{\prime}\left(B^{C}\right) / U^{\prime}\left(B^{F}\right)=I Q^{C} / Q^{F} \text { with } I \equiv(1+\rho) /(1+R)>0 \text { and } Q^{i} \equiv(1+T) P^{i}+\phi W, i=F, C .
$$

Using lower case romans to denote relative differences (or logarithmic deviations), we obtain:

$$
b^{C}-b^{F}=\alpha\left(q^{F}-q^{C}-i\right) \quad \text { with } \quad \alpha \equiv-\left(U^{\prime} / B U^{\prime \prime}\right)>0 .
$$

where $\alpha$ stands for the elasticity of substitution between books now and books in the future and consumer price differences (including sales tax and opportunity cost of reading) are given by

$$
q^{i} \cong(1-\beta)\left(p^{i}+t\right)+\beta w, i=F, C \text { with } \beta \equiv \phi W /(1+T) P^{C}
$$

Cobb-Douglas utility corresponds to $\alpha=1$. If there is no opportunity cost of the time needed to read, $\beta=0$. Consumers switch from books now to books in two years time if they expect a drop in prices as the monopoly power vanishes, if they are relatively patient and if the interest rate is high. Taking relative differences of the budget constraint and substituting relative demand for books, we obtain the demand for books now and in the future:

$$
\begin{gathered}
b^{F}=(1-\lambda) m+\lambda w-[\omega+\alpha(1-\omega)] q^{F}-(1-\alpha)(1-\omega) q^{C}+(1-\omega)(\alpha i+r) \\
b^{C}=(1-\lambda) m+\lambda w-\omega(1-\alpha) q^{F}-(1-\omega+\alpha \omega) q^{C}-\alpha \omega i+(1-\omega) r
\end{gathered}
$$

where $0<\omega \equiv Q^{F} B^{F} / M<1$ is the share of book costs in money income, $0<\lambda \equiv W /(M+W)<1$ is the 
share of potential wage income in total income, and $r$ stands for the relative difference of the gross interest rate $1+R$. Hence, the bigger the monopoly mark-up during the period of the FBP, the lower the sales of books, both now and in the future. More impatient book buyers purchase more books at monopoly prices.

Publishers/booksellers choose producer prices during the first two years and sales in both periods in order to maximize profits. With zero fixed cost and $K$ denoting (fixed) marginal cost, firms choose $B^{C}$ and $P^{F}$ to maximize the discounted stream of profits during and after the FBP:

$$
\operatorname{Max}(1+R)^{-1}\left(P^{C} B^{c}-K B^{c}\right)+P^{F} B^{F}-K B^{F}
$$

given the competitive price $P^{C}$ and the demand for books under the FBP $B^{F}$. This yields

$$
\left(P^{F}-K\right) / P^{F}=1 / \varepsilon(1-\beta) \text { and } P^{C}=K
$$

where $\varepsilon=\omega+\alpha(1-\omega)>1$ stands for the elasticity of demand for books bought during the first two years. Book sales of a particular title are in equilibrium thus given by:

$$
\begin{gathered}
b^{F}=(1-\lambda) m+(\lambda-\beta) w-(1-\beta)(k+t)+(1-\omega)\left[\alpha \rho^{\prime}+(1-\alpha) r\right]+\left(P^{F} / K\right) e \\
b^{C}=(1-\lambda) m+(\lambda-\beta) w-(1-\beta)(k+t)-\alpha \omega \rho^{\prime}+(1-\omega+\alpha \omega) r+\alpha(1-\omega)(1-\beta)\left(P^{F} / K-1\right) e
\end{gathered}
$$

where $e$ stands for the relative change in $\varepsilon$ and $\rho^{\prime}$ for that of $1+\rho$. A cut in variable costs due to, say, the advent of new information technology, or a cut in the sales tax boost sales of books, particularly if the opportunity leisure time cost of reading a book is small. Higher non-wage income boosts sales as well. Higher wage income boosts sales only if non-wage income is a relatively small proportion of total money income and the opportunity leisure time cost of reading a book is relatively small, because then the positive effect on book sales of the boost to money income more than offsets the negative effect of the rise in the cost of reading books.

\section{Acknowledgements}

When I was State Secretary for Culture and Media in the Dutch cabinet 1998-2002, I commissioned - together with the former minister of Economic Affairs Annemarie Jorritsma - the report CPB/SCP (2002) on the Dutch fixed book price. I thank Marja Appelman, Marcel Canoy 
and their excellent colleagues for preparing the detailed report and thank them and Carla de Rooi for very helpful discussions. Sections 4 and 6 owe much to their work. I thank two anonymous referees for their constructive comments and am also grateful for the hospitality provided during September 2002 at CESifo, Munich University where I wrote the first version.

\section{References}

- Akerlof, George (1970) “The market for 'lemons': Quality uncertainty and the market mechanism”. Quarterly Journal of Economics 84: 488-500.

- Bourdieau, Pierre (1979) La Distinction - Critique Sociale due Jugement. Editions de minuit, Paris.

- Cowen, Tyler (1998) In Praise of Commercial Culture. Harvard University Press, Cambridge, Ma.

- CPB and SCP (2002) Boek en Markt. Effectiviteit en Efficiëntie van de Vaste Boekenprijs. CPB and SCP, The Hague.

- Deneckere, Raymond, Marvel, Howard P. and Peck, James (1997) "Demand uncertainty and price maintenance: markdowns as destructive competition". American Economic Review 87: 619-641.

- EIM (2001) De Vaste Boekenprijs - Een Internationale 'Quick Scan'. Zoetermeer.

- European Commission (2002) "Commission accepts undertaking in competition proceedings regarding German book price fixing". Press release IP/02/461.

- Fishwick, Francis and Fitzsimons, Sharon (1998) Report into the Effects of the Abandonment of the Net Book Agreement. Cranfield School of Management.

- Grampp, William D. (1989) Pricing the Priceless - Art, Artists and Economics. Basic Books, New York.

- Hayek, Friedrich August (1988) The Fatal Conceit: The Errors of Socialism. Routledge, London.

- Holahan, William L. (1979) "A theoretical analysis of resale price maintenance". Journal of Economic Theory 21: 411-420.

- Mankiw, N. Gregory (1985) "Small menu costs and large business cycles: a macroeconomic model of monopoly". Quarterly Journal of Economics 100, 2:529-538.

- Marvel, Howard P. and McCafferty, S. (1984) "Resale price maintenance and quality certification". Rand Journal of Economics 15: 346-359.

- Mathewson, F. and Winter, R. (1998) "The law and economics of resale price maintenance". 
Review of Industrial Economics 13: 57-84.

- Ploeg, Rick van der (2002) "In art we trust". De Economist 150, 4: 333-362.

- Rosen, Sherwin (1981) "The economics of superstars". American Economic Review 71: 848858.

- Rürup, Bert, Roland Klopfleisch and Henning Stumpp (1997). Ökomomische Analyse der Buchpreisbindung. Hessischer Verleger- und Buchhändler-Verband, BüchhändlerVereinigung, Frankfurt.

- Salop, Steven and Joseph Stiglitz (1977) "Bargains and ripoffs: A model of monopolistic competitive price dispersion". Review of Economic Studies 44: 493-510.

- Sutton, John (2000). Marshall's Tendencies. What can Economists' Know?. Leuven University Press, Leuven, Belgium and MIT Press, Cambridge, Ma.

- Throsby, David C. (2001) Economics and Culture. Cambridge University Press, Cambridge.

- Tietzel, Manfred (1995) Literaturökonomik. Mohr, Tübingen.

- Tullock, Gordon (1980). "Efficient rent seeking". 3-15 in James M. Buchanan, Robert D. Tollison and Gordon Tullock, (eds.), Towards a Theory of the Rent-Seeking Society. Texas A\&M Press, College Station. 


\title{
CESifo Working Paper Series
}

\author{
(for full list see www.cesifo.de)
}

884 Eytan Sheshinski, Note on the Optimum Pricing of Annuities, March 2003

885 Paul De Grauwe and Magdalena Polan, Globalisation and Social Spending, March 2003

886 F. van der Ploeg, Do Social Policies Harm Employment and Growth?, March 2003

887 Mirjam van Praag, Initial Capital Constraints Hinder Entrepreneurial Venture Performance: An empirical analysis, March 2003

888 Bernard Steunenberg, Coordinating Sectoral Policymaking: Searching for Countervailing Mechanisms in the EU Legislative Process, March 2003

889 Eytan Sheshinski, Optimum Delayed Retirement Credit, March 2003

890 Frederick van der Ploeg, Rolling Back the Public Sector - Differential effects on employment, investment and growth, March 2003

891 Paul De Grauwe and Marc-Alexandre Sénégas, Monetary Policy in EMU when the Transmission is Asymmetric and Uncertain, March 2003

892 Steffen Huck and Kai A. Konrad, Strategic Trade Policy and the Home Bias in Firm Ownership Structure, March 2003

893 Harry Flam, Turkey and the EU: Politics and Economics of Accession, March 2003

894 Mathias Hoffmann and Ronald MacDonald, A Re-examination of the Link between Real Exchange Rates and Real Interest Rate Differentials, March 2003

895 Badi H. Baltagi, Espen Bratberg, and Tor Helge Holmås, A Panel Data Study of Physicians' Labor Supply: The Case of Norway, March 2003

896 Dennis C. Mueller, Rights and Citizenship in the European Union, March 2003

897 Jeremy Edwards, Gains from Trade in Tax Revenue and the Efficiency Case for Trade Taxes, March 2003

898 Rainer Fehn and Thomas Fuchs, Capital Market Institutions and Venture Capital: Do They Affect Unemployment and Labour Demand?, March 2003

899 Ronald MacDonald and Cezary Wójcik, Catching Up: The Role of Demand, Supply and Regulated Price Effects on the Real Exchange Rates of Four Accession Countries, March 2003 
900 R. Selten, M. Schreckenberg, T. Pitz, T. Chmura, and S. Kube, Experiments and Simulations on Day-to-Day Route Choice-Behaviour, April 2003

901 Stergios Skaperdas, Restraining the Genuine Homo Economicus: Why the Economy Cannot be Divorced from its Governance, April 2003

902 Yin-Wong Cheung, Menzie D. Chinn, and Antonio Garcia Pascual, What Do We Know about Recent Exchange Rate Models? In-Sample Fit and Out-of-Sample Performance Evaluated, April 2003

903 Mika Widgrén, Enlargements and the Principles of Designing EU - Decision-Making Procedures, April 2003

904 Phornchanok Cumperayot, Dusting off the Perception of Risk and Returns in FOREX Markets, April 2003

905 Kai A Konrad, Inverse Campaigning, April 2003

906 Lars P. Feld and Stefan Voigt, Economic Growth and Judicial Independence: Cross Country Evidence Using a New Set of Indicators, April 2003

907 Giuseppe Bertola and Pietro Garibaldi, The Structure and History of Italian Unemployment, April 2003

908 Robert A.J. Dur and Otto H. Swank, Producing and Manipulating Information, April 2003

909 Christian Gollier, Collective Risk-Taking Decisions with Heterogeneous Beliefs, April 2003

910 Alexander F Wagner, Mathias Dufour, and Friedrich Schneider, Satisfaction not Guaranteed - Institutions and Satisfaction with Democracy in Western Europe, April 2003

911 Ngo Van Long, Raymond Riezman, and Antoine Soubeyran, Trade, Wage Gaps, and Specific Human Capital Accumulation, April 2003

912 Andrea Goldstein, Privatization in Italy 1993-2002: Goals, Institutions, Outcomes, and Outstanding Issues, April 2003

913 Rajshri Jayaraman and Mandar Oak, The Signaling Role of Municipal Currencies in Local Development, April 2003

914 Volker Grossmann, Managerial Job Assignment and Imperfect Competition in Asymmetric Equilibrium, April 2003

915 Christian Gollier and Richard Zeckhauser, Collective Investment Decision Making with Heterogeneous Time Preferences, April 2003

916 Thomas Moutos and William Scarth, Some Macroeconomic Consequences of Basic Income and Employment Subsidies, April 2003 
917 Jan C. van Ours, Has the Dutch Miracle Come to an End?, April 2003

918 Bertil Holmlund, The Rise and Fall of Swedish Unemployment, April 2003

919 Bernd Huber and Marco Runkel, Optimal Design of Intergovernmental Grants under Asymmetric Information, April 2003

920 Klaus Wälde, Endogenous Business Cycles and Growth, April 2003

921 Ramon Castillo and Stergios Skaperdas, All in the Family or Public? Law and Appropriative Costs as Determinants of Ownership Structure, April 2003

922 Peter Fredriksson and Bertil Holmlund, Improving Incentives in Unemployment Insurance: A Review of Recent Research, April 2003

923 Bernard M.S. van Praag and Adam S. Booij, Risk Aversion and the Subjective Time Discount Rate: A Joint Approach, April 2003

924 Yin-Wong Cheung, Kon S. Lai, and Michael Bergman, Dissecting the PPP Puzzle: The Unconventional Roles of Nominal Exchange Rate and Price Adjustment, April 2003

925 Ugo Trivellato and Anna Giraldo, Assessing the 'Choosiness' of Job Seekers. An Exploratory Approach and Evidence for Italy, April 2003

926 Rudi Dornbusch and Stanley Fischer, International Financial Crises, April 2003

927 David-Jan Jansen and Jakob de Haan, Statements of ECB Officials and their Effect on the Level and Volatility of the Euro-Dollar Exchange Rate, April 2003

928 Mario Jametti and Thomas von Ungern-Sternberg, Assessing the Efficiency of an Insurance Provider - A Measurement Error Approach, April 2003

929 Paolo M. Panteghini and Guttorm Schjelderup, Competing for Foreign Direct Investments: A Real Options Approach, April 2003

930 Ansgar Belke, Rainer Fehn, and Neil Foster, Does Venture Capital Investment Spur Employment Growth?, April 2003

931 Assar Lindbeck, Sten Nyberg, and Jörgen W. Weibull, Social Norms and Welfare State Dynamics, April 2003

932 Myrna Wooders and Ben Zissimos, Hotelling Tax Competition, April 2003

933 Torben M. Andersen, From Excess to Shortage - Recent Developments in the Danish Labour Market, April 2003

934 Paolo M. Panteghini and Carlo Scarpa, Irreversible Investments and Regulatory Risk, April 2003 
935 Henrik Jacobsen Kleven and Claus Thustrup Kreiner, The Marginal Cost of Public Funds in OECD Countries. Hours of Work Versus Labor Force Participation, April 2003

936 Klaus Adam, George W. Evans, and Seppo Honkapohja, Are Stationary Hyperinflation Paths Learnable?, April 2003

937 Ulrich Hange, Education Policy and Mobility: Some Basic Results, May 2003

938 Sören Blomquist and Vidar Christiansen, Is there a Case for Public Provision of Private Goods if Preferences are Heterogeneous? An Example with Day Care, May 2003

939 Hendrik Jürges, Kerstin Schneider, and Felix Büchel, The Effect of Central Exit Examinations on Student Achievement: Quasi-experimental Evidence from TIMSS Germany, May 2003

940 Samuel Bentolila and Juan F. Jimeno, Spanish Unemployment: The End of the Wild Ride?, May 2003

941 Thorsten Bayindir-Upmann and Anke Gerber, The Kalai-Smorodinsky Solution in Labor-Market Negotiations, May 2003

942 Ronnie Schöb, Workfare and Trade Unions: Labor Market Repercussions of Welfare Reform, May 2003

943 Marko Köthenbürger, Tax Competition in a Fiscal Union with Decentralized Leadership, May 2003

944 Albert Banal-Estañol, Inés Macho-Stadler, and Jo Seldeslachts, Mergers, Investment Decisions and Internal Organisation, May 2003

945 Kaniska Dam and David Pérez-Castrillo, The Principal-Agent Matching Market, May 2003

946 Ronnie Schöb, The Double Dividend Hypothesis of Environmental Taxes: A Survey, May 2003

947 Erkki Koskela and Mikko Puhakka, Stabilizing Competitive Cycles with Distortionary Taxation, May 2003

948 Steffen Huck and Kai A. Konrad, Strategic Trade Policy and Merger Profitability, May 2003

949 Frederick van der Ploeg, Beyond the Dogma of the Fixed Book Price Agreement, May 2003 